\title{
Hierarquia e adulação em Antônio Vieira
}

\section{Hierarchy ANd Adulation by Antônio Vieira}

\author{
Jean Pierre Chauvin ${ }^{1}$
}

Resumo: Neste artigo, aborda-se a construção do ethos virtuoso de Antônio Vieira, a partir da leitura de sermões e missivas pregados na década de 1650, pouco antes de sua segunda vinda para o continente americano. A análise enfatiza o Sermão da primeira sexta-feira da Quaresma, pregado na Capela Real de Lisboa em 1651.

Palavras-chave: retórica; sermão; Antônio Vieira.

Abstract: In this article, we analyses the ethos's construction by Antônio Vieira, from the reading of sermons and missives preached in the 1650 , before his second travel to the American continent. This analysis emphasizes Sermão da primeira sexta-feira da Quaresma, preached in the Lisbon Royal Chapel in 1651.

Keywords: Rhetoric; Sermon; Antônio Vieira.

"Quando comprares um escravo hebreu, seis anos ele servirá; mas no sétimo sairá livre, sem nada pagar."

(Êxodo: 21) ${ }^{2}$

“[...] a conversão desses bárbaros jamais se fará pelo amor, mas somente depois de tê-los subjugado pela força das armas e torná-los vassalos do rei nosso senhor."

(Gaspar Simões) ${ }^{3}$

${ }^{1}$ Departamento de Jornalismo e Editoração da Escola de Comunicações e Artes (USP): $<$ tupiano@usp.br>.

${ }^{2}$ Bíblia de Jerusalém (2015, p. 132).

3 "Carta de Gaspar Simões para o provincial jesuíta, datada de Luanda, 20 de outubro de 1575” (Cf. BOXER, 2007, pp. 94 e 163). 


\section{MATÉRIA}

O Cântico dos cânticos menciona uma rica liteira sustentada por sessenta homens e que carregava o Rei Salomão. Lá, e também nos Salmos, vemos o modo como seu pai, Davi, procedera implacavelmente em relação aos inimigos e aduladores. ${ }^{4}$ Para além da reafirmação do poder, essas historietas muito interessam porque também ilustram um dos argumentos centrais sustentados por Antônio Vieira no Sermão da primeira sexta-feira da Quaresma, pregado na Capela Real de Lisboa em 1651. Com habilidade, o orador recorre à conduta de Davi e seu filho, em provável analogia com a sucessão dos monarcas portugueses, em particular de Dom João IV - que possivelmente assistiu ao sermão, ${ }^{5}$ embora comece a se afastar do Confessor Real, naquele momento. Para além das várias alusões às escrituras, obras da patrística e tratados filosóficos, o discurso também chama atenção pelo modo como foi disposto. Logo à segunda frase, o pregador menciona as faculdades da alma, conforme as definia Santo Agostinho ${ }^{6}$ - uma das auctoritates recorrentes a que Vieira busca e se afilia, ${ }^{7}$ com o intuito de reforçar a consistência do argumento, levando em conta o auditório mais homogêneo ${ }^{8}$ e discreto $^{9}$ que o escutaria.

\footnotetext{
${ }^{4}$ Para intimidar os pecadores e realçar o poder atribuído a Deus, os vícios relativos ao caráter constituem uma das tópicas fundamentais e estruturantes do discurso bíblico. Em Salmos, 12 (11), lê-se: "Socorro, Iahweh! Não há mais homem fiel!/ A lealdade desapareceu dentre os filhos de Adão!/ Cada qual mente ao seu próximo, falando/ com lábios fluentes e duplo coração" (BÍBLIA, 2015, p. 873). Nos Provérbios 11 (3), encontra-se a máxima de que "A integridade guia os homens retos,/ e a maldade destrói os traidores" (p. 1.036). O Salmo 18 (17), a que se refere Vieira (2015, p. 199), subintitula-se "Te Deum Real” e se atribui a "Davi, servo de Iahweh" (BÍBLIA, 2015, p. 877).

5 "[Os] sermões na Capela Real portuguesa [...] eram dirigidos às mais altas autoridades do reino, incluídos o rei e a rainha” (PÉCORA, 20o8, p. 47).

6 "Deixemos de lado, por enquanto, os demais atos de que a alma está certa de lhe pertencer como propriedade, tratemos agora das três faculdades já antes consideradas: a memória, a inteligência e a vontade" (AGOSTINHO, 2016, p. 330).

7 É a isto que se chama o conceito predicável, método argumentativo utilizado na oratória sacra do Seiscentos e que se baseava na autoridade do texto sagrado, tomado como "conceito" ou metáfora que o orador desenvolvia, interpretando-o (LEMOS; RAMON, 2015, p. 14).

8 “[...] em matéria de retórica, parece-nos preferível definir o auditório como o conjunto daqueles que o orador quer influenciar com sua argumentação [...] A retórica, tornada exercício escolar, dirige-se a auditórios convencionais e pode, sem inconvenientes, ater-se a visões estereotipadas deles, o que contribuiu, tanto quanto a artificialidade dos temas, para fazê-la degenerar. A argumentação efetiva tem de conceber o auditório presumido tão próximo quanto o possível da realidade" (PERELMAN, 1996a, p. 22).

9 "Agudeza, prudência, dissimulação, aparência e honra constituem a discrição. Nas monarquias absolutistas do século XVII, principalmente nas ibéricas, a discrição é
} 
Recorde-se que no ano anterior a essa pregação na Capela Real, eminentemente voltada para o auditório palaciano, o jesuíta foi enviado à Itália, em missão a mando do Rei, ${ }^{10}$ para desembaraçar questões de natureza diplomática, sem lograr total êxito. Seria razoável supor que Vieira - em meio à murmuração dos olheiros, maquinações de cortesãos e movimentos da Corte -, tenha composto esse sermão, também, para dar testemunho público de sua fidelidade e sujeição a João IV,, e, simultaneamente, alertá-lo sobre os "inimigos internos" ou "aduladores" do reino? Em caso afirmativo, ao proceder dessa maneira, teria feito da oratória escudo verbal, face aos rumores sobre a queda de seu prestígio e menor influência junto ao Rei, como sugerem algumas correspondências e outros documentos daquele período.

Por exemplo, na carta enviada a D. João IV em 28 de fevereiro de 1650, o jesuíta tenta abrir os olhos do Rei para dois membros da Companhia de Jesus em missão - um pela falta de caráter; outro, pela incapacidade de guardar segredo das questões do reino. Em relação ao primeiro, "[o] Padre Nuno da Cunha [...] não trata mais que de adiantar as pretensões de seu irmão e suas, fazendo degrau do serviço de Vossa Majestade sobre o qual põem os pés" (VIEIRA, 2014a, p. 293). Quanto ao segundo, "Manuel Alves Carrilho tem muito bom zelo, mas tudo crê e tudo fala; e sem segredo nem consideração mal se podem obrar negócios que pedem tanta" (p. 293). Meses depois, dirige-se ao Príncipe Teodósio de Bragança (primogênito de Dom João IV) com missiva remetida em 26 de maio de 1650, onde sugere que, “Como há poucos Antônios Vieiras, há também

padrão nuclear da racionalidade de corte que define o cortesão, proposto para todo o corpo político do Estado como o modelo do uomo universale, o homem universal, como dizia Castiglione no século XVI. Nas práticas de representação, a discrição é categoria intelectual que classifica ou especifica a distinção e a superioridade de ações e palavras, aparecendo figurada no discreto, que é tipo ou personagem dos processos de interlocução. Etimologicamente, o substantivo discreto, como em o discreto, é a forma do particípio passado do verbo discernir" (HANSEN, 2019a, p. 104).

1o "O cardeal Armand Richelieu declarou certa vez que nada o havia impressionado tanto como a afirmação de certo espanhol prudente de que o fundamento tríplice do poderio espanhol eram: Mar, Consejo y Roma. Ao império ultramarino (= Mar) e à administração fiel ao rei e à lei (= Consejo, conselho) deve somar-se a ortodoxia católica (= Roma). Só isto tudo junto é Espanha" (HÖFFNER, 1986, p. 93).

11 “A metáfora do 'corpo' é substancializada nos textos neoescolásticos dos séculos XVI e XVII; no caso de Portugal, é apropriada na doutrina do 'pacto de sujeição' do 'corpo místico do Estado’ feita por Francisco Suárez em De Legibus, tornando-se um dos fundamentos do direito absoluto e do direito ordinário também no Estado do Brasil, onde regula o exclusivo monopolista e a ação jesuítica" (HANSEN, 2019b, pp.78-79). 
poucos que amam só por amor; e assim Sua Majestade não deve esperar finezas, senão contentar-se muito de que se queiram vender aqueles que lhe for necessário comprar" (VIEIRA, 2014a, p. 297).

$\mathrm{Na}$ carta de fevereiro, o conselheiro reivindica e encena um de seus papéis junto ao reino: zelar pelas contas e companhias do Rei. Na carta de maio, dialoga (ainda que pelo avesso) com o que Maquiavel aconselhava nO príncipe, ${ }^{12}$ sobre a astúcia e violência do governante, com mais de um século de antecedência. Na correspondência a Dom João IV, Vieira reforça o ethos de juiz, súdito fiel e atento às questões do reino, dentro e fora de Portugal. Na carta a Teodósio, alude ao pai do Príncipe e destaca a importância de o Rei zelar pelo amor de seu povo, através de gestos caritativos (e não necessariamente honestos).

De modo similar, o Sermão da primeira sexta-feira da Quaresma enaltece a charitas, virtude ainda mais exemplar quando praticada pela autoridade máxima do governo temporal, isto é, o Rei. Em seguida, Vieira submete todos (também Dom João IV) ao mandamento de que seria preciso "amar os inimigos". Finalmente, divide os inimigos do reino entre os "externos", que porventura não amem o Rei, situados para além dos muros do palácio; e os "internos", costumeiramente mais próximos do Rei, que fingem amá-lo. Ao distribuir a matéria desse modo, Antônio Vieira recorda que os amigos edificam; os aduladores cobiçam; os súditos fiéis corrigem ações do Rei; os inimigos dissimulam a verdade e simulam elogios, já que sua alma é inconsistente e seu caráter inconstante.

Em outro sentido, os aduladores da Corte seriam homens pérfidos que agiriam de modo similar aos hereges, em particular, os gentios ${ }^{13}-$ perspectiva que permitiria evocar muitos outros sermões de Vieira (2015c,

\footnotetext{
12 "Porque, avançando os homens sempre por caminhos batidos por outros e procedendo em suas ações por imitação, mas, sem poder seguir à risca a trilha de outrem nem alcançar a virtude daquele que se imita, um homem prudente deve tomar sempre a via trilhada por homens ilustres, que foram exemplos excelentíssimos a serem imitados: e, não sendo possível ombrear-lhes a virtude, que ao menos se deixe algum vislumbre dela; e que se faça como os arqueiros sensatos, os quais, diante de um alvo demasiado distante, e conhecendo até onde vai a potência de seu arco, alçam a mira muito mais alta que o ponto de destino, não para alcançar com suas flechas tanta altura, mas para poder, com o auxílio de tão alta mira, atingir a sua meta" (MAQUIAVEL, 2010, p. 44).

${ }_{13}$ Uma das teses recorrentes no documento elaborado entre 1545 e 1563, pelo Concílio de Trento (1953, p. 10), deixa clara a seletividade com que a graça divina se estenderia aos homens: "Embora tenha ele morrido por todos (2 Cor 5, 15) não obstante nem todos recebem o benefício da sua morte, mas somente aqueles aos quais é comunicado o merecimento de sua Paixão".
}

Remate de Males, Campinas-SP, v.40, n.2, pp. 751-766, jul./dez. 2020 - 754 
p. 8o), a exemplo do Sermão pelo bom sucesso das armas de Portugal contra as de Holanda, pregado em 1640, na Bahia: "A Seita do Herege torpe, e brutal concorda mais com a brutalidade do bárbaro". Isso nos leva a cogitar que a relação dos jesuítas em relação aos índios certamente não era percebida como ambivalente ou contraditória, ${ }^{14}$ durante os séculos XVI e XVII. Conforme salienta Alcir Pécora (2005, pp. 89-90):

\begin{abstract}
Visto no interior do corpo místico a que passa a pertencer, o gentio ocupa um lugar hierárquico definido, pelo qual responde jurídica, política, moral e religiosamente. [...] Sem retirar o sentido originalmente injusto da escravidão, Vieira considera que a nova situação vivida pelo gentio, desde que o faça ingressar na religião cristã, é melhor do que a anterior, ignorante de Cristo, ainda que livre. Pois, catolicamente, apenas agora, mesmo cativos, os gentios conheciam a liberdade, que não se define como ausência de subordinação temporal a um senhor, mas como exercício do arbítrio que reconhece e elege para si o bem de Cristo.
\end{abstract}

Salvo engano, haveria cabimento em discutir a construção do ethos virtuoso com que Vieira pretende justificar a confiança depositada pelo Rei. Para isso, o pregador mobiliza vasto repertório, pautado pela Teologia, pela Filosofia e pela Política, com o fim de descrever e classificar os membros da corte como amigos ou inimigos do reino. Poder-se-ia afirmar que o pregador descreve uma morfologia da corte e demonstra que o exercício da caridade não compete aos súditos: é virtude maior, reservada ao Rei, segundo a lógica embutida na razão de Estado que embalou Portugal até o início do século XIX.

\title{
DIVISÃO
}

Quando examinamos a obra de Antônio Vieira, importa lembrar que seus escritos foram constantemente submetidos à mesa censória do Tribunal do Santo Ofício. É ilustrativo dessa operação o longo período durante o qual enfrentou a Inquisição portuguesa. A questão é instigante, pois também pode se relacionar aos sermões pregados pelo jesuíta. Isso porque os autos do processo movido contra o padre incluíram textos e

\footnotetext{
${ }_{14}$ "Durante séculos, a união entre cruz e coroa foi representada pela instituição da patronagem real - a palavra é esta mesmo, apesar de sua associação com a escravidão no 'Velho Sul' - da Igreja ultramarina por parte das Coroas ibéricas: o Padroado real, em português, e o Patronato (ou Patronazgo) em espanhol. O padroado real português pode ser definido em geral como uma combinação de direitos, privilégios e deveres concedidos pelo papado à Coroa de Portugal na qualidade de patrocinadora das missões católicas e dos estabelecimentos eclesiásticos missioneiros na África, Ásia e Brasil” (BOXER, 2007, p. 98).
} 
relatos sobre o contato de Vieira com os heréticos e mesmo a interferência nos negócios da Coroa. Adma Muhana (2008, p. 14) atenta para a circunstância de que:

Não suscitando propriamente questões interpretativas, a principal questão que essa correspondência coloca para a compreensão do Processo, a meu ver, é a da sua finalidade. Declarações datadas de 1663, denúncias de 1649 e 1656 e outros documentos só serão agregadas ao Processo a partir da prisão de Vieira, em 1665, quando a disposição de condená-lo faz com que todos os indícios antecedentes sejam agrupados para compor as provas.

Seria possível detectar tais interferências, murmuradas entre os cortesãos, no Sermão da primeira sexta-feira da Quaresma? Consideremos os pressupostos, métodos e objetivos do orador. $\mathrm{O}$ decoro ${ }^{15}$ se estabelece pela menção, nas primeiras linhas, aos livros do Antigo Testamento (Cânticos e Salmos), que relembram o preceito de fazer o bem aos inimigos. ${ }^{16}$ Ao desenvolver a exposição, respaldada por inúmeros exemplos colhidos dentro e fora das escrituras, censura os aduladores, que fingem amar o Rei. Nas seções finais, embora faltasse a "Peroração", ${ }_{17}$ exorta os ouvintes a amarem ${ }^{18}$ e serem obedientes a Deus e a Dom João IV, como dispunham o Evangelho e as Leis do reino, em conformidade com o conceito de corpo místico. Sob esse aspecto, ele parece seguir as antigas lições que orientavam a educação e a prática dos religiosos, desde muito jovens, como recomendava a Cartinha com os Preceitos e Mandamentos

15 "É parte do decorum do sermão, portanto, adaptar-se à ocasião para modificá-la segundo uma Ordem que lhe é superior, a fim de atualizar a palavra divina e mover o auditório de maneira eficaz" (PÉCORA, 2016, p. 14).

${ }^{16}$ Aplica-se o expediente que Alcir Pécora (2016, p. 53) percebeu no Sermão da quarta-feira de cinza: "Vieira retarda o quanto pode, contudo - bem de acordo com o preceito engenhoso de suspender os ânimos do auditório -, a explicação do que entende ser essa morte voluntária”.

${ }_{17}$ "Jacinto do Prado Coelho justifica essa aparente falha na estrutura do sermão dizendo que ela ficaria a dever ao pudor de Vieira em afrontar o Rei que muito presumivelmente assistiria à pregação: 'O sermão de Vieira apresenta a estrutura consagrada: compõe-se [...] finalmente da 'peroração', em que, tirando do que foi dito o ensinamento, exorta os fiéis a pô-lo em prática” (LEMOS; RAMON, 2015, p. 20).

18 "O que essas práticas visam produzir éa imagem, ao mesmo tempo verossímil e persuasiva, do poder político e de sua legitimidade para a adesão de auditórios variados às finalidades do Estado e da Igreja. No limite, o que eles visam é a produção afetiva da concórdia (ou uma ordem fundada no amor) dos vassalos da coroa, distribuídos hierarquicamente, sem que isso se separe da sua própria razão de ser: a saúde do corpo místico do império" (LUZ, 2013, p. 52).

Remate de Males, Campinas-SP, v.40, n.2, Pp. 751-766, jul./dez. 2020 - 756 
da Santa Igreja de João de Barros (2008, p. 99), que circulou no reino a partir de 1539:

[...] deixadas muitas divisões que os católicos fazem do ofício da missa, nós o repartimos em três partes para os meninos, cuja esta obra é para que tenham doutrina conforme a sua idade. A primeira parte será material: em que se contém as coisas materiais dela, com declaração do que significam. A segunda espiritual, em que se tratam das orações, modulações, autos e cerimônias espirituais, dando delas alguns significados e é assim que os pontífices as ordenaram. A terceira será moral, em que veremos o que deve fazer todo fiel Cristão enquanto nela estiver. ${ }^{19}$

Em possível aplicação do ensinamento de Barros, no Sermão da sexagésima, Vieira (2015b, p. 53) defende o discurso claro e didático em contraposição ao "xadrez de palavras", promovido, segundo ele, pelos oradores dominicanos:

\begin{abstract}
Mas como em um pregador há tantas qualidades, e em uma pregação tantas leis, e os pregadores podem ser culpados em todas; em qual consistirá essa culpa? No pregador podem-se considerar cinco circunstâncias: a Pessoa, a Ciência, a Matéria, o Estilo, a Voz. A pessoa que é; a ciência que tem; a matéria que trata; o estilo que segue; a voz com que fala.
\end{abstract}

Consideremos o emprego dessas "cinco circunstâncias", no Sermão da primeira sexta-feira da Quaresma. A Pessoa (Antônio Vieira) dispõe de vasto conhecimento (Ciência), repertório (Matéria), decoro (Estilo) e eloquência (Voz). Recordando que o assunto de que o sermão tratava (Inventio) era exortar o Príncipe a amar aos inimigos e se precaver contra os aduladores, passemos à Dispositio. Distribuído em nove partes, o sermão foi organizado como abordagem proporcional da matéria, sugerindo que, tanto as sentenças que produziriam maior flama, quanto os períodos frasais que indicam menor potência durante a enunciação, reforçam o ethos do orador e pretendiam afetar as paixões do seleto auditório Real. É possível que a preocupação com o ajuizamento do seleto auditório teria levado Vieira a recorrer a determinados repertórios, adequados ao assunto que explanaria, em conformidade com o estilo conveniente para produzir maior efeito e persuadir os ouvintes, como ensinava Santo Agostinho:

A Bíblia, para Agostinho, discorria sempre sobre assuntos decisivos e importantes para a salvação da alma, servindo-se destes três estilos conforme a finalidade do

${ }^{19}$ A grafia original dos textos antigos foi mantida.

Remate de Males, Campinas-SP, v.40, n.2, pp. 751-766, jul./dez. 2020 - 757 
seu discurso. Transmitia conceitos pelo estilo simples; louvava e censurava pelo estilo médio; persuadia pelo estilo sublime (BENTO, 2019, p. 55).

A maneira como as partes do sermão foram dispostas reforçava não só a exposição em breves etapas de argumentos retos, claros e didáticos, mas também reproduzia, em diferente escala, o modo ordenado das seções e a subordinação sintática dos períodos. Dessa perspectiva, o sermão estava para as suas partes, assim como estas para os períodos frasais. A subordinação sintática das frases também refletiria, na esfera microtextual, a submissão dos membros-ouvintes à Igreja e ao Reino??o Hipótese a considerar. De todo modo, o que sabe é que a dupla sujeição permeava a forma mentis e a condução dos homens, como mostrou Joseph Höffner (1986, p. 21):

Da cristianização do antigo império surgiu o ideal de dois chefes à frente da cristandade, Papa e Imperador. Tornou-se tarefa sumamente difícil a separação clara entre as esferas religioso-pontifícia e político-imperial, devido à profunda penetração da mentalidade religiosa cristã em todos os domínios da vida medieval.

O exame das nove partes do Sermão da primeira sexta-feira da Quaresma pode ilustrar o senso de proporção aplicado ao texto, quando de sua provável reescrita. Duas partes (I e II) estão voltadas para a introdução da matéria. Cinco partes (III a VII), para o desenvolvimento das hipóteses. Duas partes (XVIII e IX) contêm as teses com que Vieira confirma as hipóteses. Aproximemo-nos do texto, conforme ele se divide:

\begin{abstract}
Seção I - As Pessoas soberanas são superiores a toda a Lei, e por isso será necessário examinar exatamente até onde se estende o preceito de Cristo, e resolver com a Graça do mesmo Senhor, e sem lisonja de nenhum outro, se são obrigados também os Reis a amar seus inimigos (VIEIRA, 2015a, p. 197).

Seção II - Não seriam as Majestades, se se sujeitassem a amar. Por quê? Por outras duas razões de sua parte. Amar é inclinar-se à vontade primeiro, e depois render-se; e o render-se é contra a potência da Majestade, o inclinar-se contra a soberania (p. 199).

Seção III - De tão longe ia Deus estabelecendo, e fundando já o preceito que hoje havia de promulgar por Sua própria boca, ensinando com tão graves, e temerosas experiências aos Reis que quando dissesse: Ego dico vobis [Eu digo vós], também falava com eles (p. 204).
\end{abstract}

\footnotetext{
zo "Percebemos [...] a necessidade de entender Vieira e suas ideias dentro da 'gramática' da época, sem buscar no jesuíta um pensador moderno e progressista ou ainda um 'teólogo da libertação avant la lettre." (LIMA, 2004, p. 23).
}

Remate de Males, Campinas-SP, v.40, n.2, Pp. 751-766, jul./dez. 2020 - 758 
Seção IV - A maior autoridade, e soberania dos Reis é que nas controvérsias com outros Príncipes estranhos eles sejam, e Deus fiasse deles o serem juízes em causa própria (VIEIRA, 2015a, p. 207).

Seção V - É certo que [os aduladores] não são os que lavram os campos, nem os que aram os mares, nem os que presidiam as torres, nem os que pleiteiam nos Tribunais, nem os que comerceiam nas praças, nem mesmo os outros, que com o trabalho de suas mãos servem à República, e só conhecem de Palácio as paredes, e as adoram de fora (p. 209).

Seção VI - E posto que as suas palavras (como pede o respeito, e reverência real) se pronunciem vestidas, ou adornadas com alguns daqueles enfeites, que popularmente se chamam lisonjas, nem por isso desmerece o afeto de seus corações o nome de amigos, e verdadeiros amigos (p. 213).

Seção VII - [...] é bênção, ou fatalidade dos Reis que tudo o que fizerem, ou quiserem, ainda que não seja louvável, seja louvado (p. 215).

Seção VIII - [...] como o Norte sempre fixo do adulador é o interesse, e conveniência própria, nenhum há que se fie deste seguro real, e todos temem arriscar a graça, onde têm posta esperança. Dizia Sêneca (e dizia o que obrava) que "antes queria ofender com a verdade, que agradar com a lisonja" (p. 218).

Seção IX - [...] adular é querer mal, e ser adulador é ser inimigo; e quantos são os euges que vos dizem, tantos são os males que vos querem (p. 223).

Percebe-se que o discurso se orienta simultaneamente em múltiplas direções, para além da caracterização de amigos ou aduladores do reino. Antônio Vieira discorre sobre temas muito caros aos jesuítas, dentre os quais, a dupla hierarquia do Amor, natural, em relação a Deus; o compulsório, dos súditos em direção ao Rei (Seções I e II); a hierarquia aplicável a todos os católicos em relação a Deus (Seção III); a guerra justa, como prova de amor, pois se faria o bem por intermédio da correção moral no campo de batalha (Seção IV); o lugar dos amigos e dos aduladores no reino (Seção V); os modos de reconhecer os amigos do Rei (Seção VI); o poder soberano dos Reis (Seção VII); os expedientes utilizados pelos aduladores (Seção VIII); a simulação de amizade por meio da lisonja (Seção IX).

Nesse caso, o discernimento do ouvinte envolveria quatro faculdades: compreender a matéria de que Vieira tratava; identificar as técnicas a que recorrera, ao inventar e dispor as partes do sermão; estabelecer relação entre os reis, teólogos e filósofos, evocados no sermão, com a sabedoria ${ }^{21}$

${ }_{21}$ "Um dos preceitos mais recorrentes e fundamentais tanto nas Diatribes como no Encheiridon de Epicteto é a distinção entre aquilo que está sob o controle da razão humana e aquilo que não está. O que o ser humano controla é apenas sua prohairesis: seu 'propósito moral' ou sua capacidade de antecipação e escolha prévia, para que faça o uso correto das 'impressões externas' das phantasias (conforme, por exemplo, Diatribes, I, 1; e Encheiridon, 1). Dessa forma, uma conduta virtuosa, para Epicteto, resume-se ao sustine et abstine [suporta e tolera]: é preciso negligenciar as coisas externas para que se mantenha o 'propósito moral' (Encheiridon, 13)" (LACHAT, 2016, p. 21).

Remate de Males, Campinas-SP, v.40, n.2, pp. 751-766, jul./dez. 2020 - 759 
que se espera dos homens poderosos e discretos, em particular Dom João IV; aplicar o preceituário, apresentado pelo jesuíta, à conduta do súdito que o escutava pregar.

\section{ARTIFÍCIO}

Alcir Pécora (2008, pp. 40-46) salienta que a construção da imagem de Antônio Vieira variou sobremodo ao longo dos tempos. Dentre as virtudes e vícios apontados pela extensa fortuna crítica e biográfica do jesuíta, discorre-se sobre beletrismo, oportunismo, altruísmo e humildade; reafirma-se a sua incansável ação apostólica; atrela-se a ele a estatura de Pajé-Açu etc., o que não impede ver, em parte de suas palavras e condutas, gestos judaizantes e, portanto, suspeitos de heresia. Seria um truísmo lembrar que, assim como há múltiplos Vieiras, existem várias espécies de sermão, dispostos segundo o teor da matéria, os pressupostos que os animam, os métodos que os embalam, os estilos convenientes e os fins pretendidos pelo orador, tendo em vista o auditório a quem se dirige. $\mathrm{O}$ ato de pregar é observado com extrema atenção por aqueles que escutam o orador falar. Ainda, Lemos e Micaela Ramon (2015, p. 11) lembram que:

[...] o sermão foi não só o gênero literário predominante, mas também a base da mais importante cerimônia social do século XVII: a pregação. Através dela, a palavra do orador atingia todas as camadas sociais e, por isso mesmo, o ato de pregar revestia-se de uma importância fundamental. [...] Daí que o púlpito fosse utilizado como tribuna ideal não só para a difusão da palavra de Deus, como também para o comentário crítico da vida pública.

Em sua já citada Cartinha, João de Barros produz uma metáfora que aproxima o sino da igreja e o padre da missa, um a chamar, outro a exortar os fiéis: "O vaso do sino significa a boca do pregador, e em ser de metal, denota a força de seu entendimento. E o badalo, que o faz soar dando em uma e em outra parte, é a língua do pregador que toca em ambos os testamentos, o Novo e o Velho" (BARROS, 2008, p. 99). Esse tipo de imagem, sugerida pela aproximação de objeto e função, assume a componente alegórica, ${ }^{22}$ maiormente nos sermões, o que explica, no caso

\footnotetext{
22 "O uso da alegoria na parenética é fundamental, uma vez que o sermão atualiza a palavra de Deus para a audiência. Assim, as estratégias de acomodação do texto bíblico à realidade vivida pelos fiéis, por meio, no caso de Vieira e dos demais pregadores jesuítas de seu tempo, pelo menos, de uma retórica reaquecida pelos retores da Companhia, passam não apenas pelo conhecimento desse maquinário retórico, mas também do teológico, do qual não se separam” (MARTINI, 2019, p. 101).
}

Remate de Males, Campinas-SP, v.40, n.2, pp. 751-766, jul./dez. 2020 - 760 
de Vieira, o constante recurso ao dogma e a demais preceitos, com que redimensiona a extensão das figuras para quem ou sobre as quais discorre. Inicialmente, poderíamos sugerir que o sermão é arte que, orientada por preceitos, preceitua. Ou seja, calcado em preceitos retóricos, fundado no dogma e obediente às leis, canônica e civil, ${ }^{23}$ pressupõe performance ajustada ao modo como é composto, ordenado e enunciado. Como afirma João Adolfo Hansen (2018, pp. 75-76):

Tanto os sujeitos de enunciação quanto os destinatários implícitos são modelados com caracteres que os particularizam e posicionam como membros de estamentos e ordens sociais do corpo místico do Estado ou membros da unidade de uma mesma vontade coletiva subordinada ao rei no pacto de sujeição. Dramatizados pela actio, a ação do corpo, e pela pronuntiatio, a voz da enunciação, os discursos orais constituíam seus destinatários implícitos como membros da totalidade do "público" colonial, unificado e hierarquizado nas representações como testemunhos da sua própria subordinação ao bem comum do Império.

Margarida Miranda propõe que os expedientes retóricos se coadunavam a outros artifícios, empregados com maestria por Antônio Vieira:

Com a metáfora da funda de David, o Padre António Vieira expunha a sua convicção sobre a eficácia da palavra como arma de arremesso, que derruba, fere e vence os inimigos. $\mathrm{O}$ orador não esquecia porém que era necessário pregar palavras e obras. O poder persuasivo dos sermões de Vieira deveu-se também certamente ao ethos do pregador. O topos "pratica o que pregas", lugar comum da tradição apostólica mas também da tradição retórica pagã, é abundantemente ilustrado pela pregação de Vieira, nomeadamente pela já apresentada metáfora bíblica da funda de David: "Antigamente convertia-se o mundo; hoje porque não se converte ninguém? Porque hoje pregam-se palavras e pensamentos, antigamente pregavam-se palavras e obras. Palavras sem obras são tiro sem bala; atroam mas não ferem. A funda de David derrubou o gigante, mas não o derrubou com o estalo, senão com a pedra [...]” (MIRANDA, 2008, p. 269).

23 "A coroa é um corpo composto, segundo uma hierarquia particular, pelo rei e pelos magnatas, corresponsáveis pela condução do corpus mysticum [corpo místico]. Na teologia política neotomista, própria do universo político ibérico dos séculos XVI, XVII e XVIII, tal noção de coroa se articula à tópica da 'obediência ao poder público' como algo inscrito na lei natural. Para Francisco de Vitória, por exemplo, o poder da sociedade política tem sua origem na Providência, que reúne os cidadãos como parte de um só corpo, mantendo-o como totalidade indivisível. Assim, por um lado, o cargo real é a corporificação da união mística do povo, sob uma mesma coroa, na persona ficta do governante a quem se deve obediência; por outro, há um compromisso inalienável do rei com os cidadãos na distribuição de responsabilidade em relação ao bem comum" (LUZ, 2013, p. 38). 
Para os fins desta breve reflexão, consideremos os artifícios enunciativos explicitados pelo pregador no Sermão da primeira sexta-feira da Quaresma. Nele, há pelo menos quatro passagens em que Vieira chama atenção para aspectos relacionados à matéria, ao estilo e ao expediente retórico empregado na construção do próprio discurso. Esses expedientes se localizam nas seções finais do sermão. Desnudados pelo orador, os artifícios parecem redobrar, pela aparente transparência do método e flama controlada pelo pregador, a consistência teológico-política e a sinceridade exortativa dos argumentos. Recorde-se que o sermão é pregado para um auditório seleto e se dirige especialmente ao Rei Dom João IV. Na transição entre as seções VI e VII, lemos o seguinte:

[...] quantos forem em Palácio os inimigos de seus interesses, tantos são os inimigos dos Reis. E se eles disserem que são isto discursos, também eu folgara muito que não só foram discursos, senão muito mal fundados, e muito falsos; mas no nosso mesmo Texto o Benefacere é prova do Diligere: Diligite, et benefacite (VIEIRA, 2015a, p. 215).

Vieira relembra o nexo causal entre amar [Diligere] e fazer o bem [Benefacere], em conformidade com a disposição hierárquica da Corte. Assim como os desígnios de Deus, a vontade dos Reis não pode ser colocada em questão. Quando um súdito age contrariamente aos "interesses” do soberano, procede como "inimigo interno", um "adulador". Se se tratar de um cortesão, ou seja, de um membro do palácio, deverá ser apontado e denunciado como adulador, e não amigo do Rei.

Na sétima parte, topamos com esta curiosa analogia: "para que eu também acrescente a minha comparação, são parecidos os aduladores àqueles quatro animais do Apocalipse" (VIEIRA, 2015a, p. 217). Nesse excerto, o pregador afeta modéstia ao acrescentar a "sua" comparação àquelas que colheu em numerosas fontes, tanto teologais quanto filosóficas. Ao construir a imagem por aproximação, pretende colaborar para o rebaixamento moral e físico dos aduladores, identificados às duas bestas que aparecem no livro Apocalipse. Uma delas lembra um leopardo com cabeça de leão e patas de urso. A segunda besta, emergida da terra, tem dois chifres, o que lembra a figura de um cordeiro. O adulador, inimigo palaciano, seria um leopardo disfarçado em cordeiro? Parece que sim, tendo em vista que as más intenções do inimigo do Rei são mascaradas pelo discurso elogioso, mas bajulador e falso.

Já na oitava seção, lê-se: "Reparai muito nesta última cláusula, que em moral, e político sentido fecha admiravelmente todo o nosso discurso: 
Quia santificatio Regis est, et domus Regni est24" (VIEIRA, 2015a, p. 221). No excerto, Antônio Vieira ressalta que o adulador não tem coragem de dirigir críticas ao soberano. Por isso, reaproveita a sentença que descreve o Palácio como sinédoque dos súditos do Rei. Decorre daí a interpretação de Vieira, para quem as ações do Rei costumam ser santificadas, jamais criticadas, pelos aduladores (que costumam ser os mais próximos, espacialmente, em relação ao monarca). Na última seção (IX), encontra-se o seguinte:

\begin{abstract}
Suposto pois que os aduladores são inimigos dos Reis, e os Reis como todos os outros Cristãos têm também obrigação de amar a seus inimigos, e fazer-lhes bem; seguia-se agora exortar os Príncipes a este amor, e beneficência; Diligite inimicos vestros, et benefacite his, qui oderunt vos. Mas este meu Sermão hoje será a primeira oração Evangélica, que contra todas as Leis da Retórica acabará sem peroração (VIEIRA, 2015a, pp. 222-223).
\end{abstract}

Nessa passagem, Vieira recorda a tese de que os aduladores são inimigos dos Reis, à qual emenda o preceito cristão de que é preciso amar os inimigos. Embora afirme que o sermão não contém "peroração" parte final do discurso em que o orador apela à compaixão do ouvinte (o movere, ensinado por Cícero e Quintiliano) -, a última seção é exortativa e cumpre precisamente a função de deslocar (portanto, mover) as paixões do auditório. $\mathrm{O}$ fato de o orador negar que recorre à peroração não impede que busque sensibilizar os ouvintes: ponto alto de sua fala do púlpito, concebida e performada para a elocução ora sóbria, ora inflamada, ora tênue. Antônio Vieira não só está consciente de "todas as Leis da Retórica”, como também afeta a impassibilidade de um sábio (gesto sabidamente caro aos estoicos), como sinal de moderação, entendimento e memória dos ensinamentos de Jesus Cristo. Os lances finais pretendem reavivar a chama dos ouvintes, uma vez seduzidos pelos artifícios forjados pelo discurso íntegro, pronunciado por um pregador que projeta um ethos virtuoso (aparentemente honesto e espontâneo), que performa de modo eficaz e eficiente o papel de conselheiro, e não de adulador, do Rei.

Talvez fosse o caso de retomar a ideia de que o sermão materializava procedimentos em acordo com a matéria, o modo como ela era distribuída e se adequava à elocução conveniente do pregador. Compreendido como gênero discursivo que previa e ensinava determinado auditório (ora mais, ora menos homogêneo), para o sermão convergiam preceitos com que se

24 “[...] Desde a santificação do Rei, a casa real".

Remate de Males, Campinas-SP, v.40, n.2, pp. 751-766, jul./dez. 2020 - 763 
prescreviam modos de conceber, agir e ser. Claro está que esses modos não se aplicavam da mesma forma e com a mesma intensidade aos variados membros do corpo místico, afixados pela rígida hierarquia administrativa. Antes de tudo, o sermão reforçava a partição da sociedade do antigo Estado português. A caridade do Rei era tão superior quanto o éter e não se confundia com o amor compulsório que emanaria dos súditos. Por sua vez, o homem branco e católico, duplamente submetido à "verdadeira" fé e às leis do reino, distanciava-se do gentio - descrito como criatura bárbara, inocente e inconstante desde a "conquista" de Pindorama. ${ }^{25}$

\section{$\overline{\text { REFERÊNCIAS }}$}

AGOSTINHO, Santo. A Trindade. 6. reimp. Trad. Augustinho Belmonte. São Paulo: Paulus, 2016.

BARROS, João de. Cartinha com os Preceitos e Mandamentos da Santa Madre Igreja. Org. Gabriel Antunes de Araújo. São Paulo: Humanitas/Paulistana, 2008.

BENTO, Emilson José. Retórica e exegese na pregação cristã. In: HUBERT, Elizabete Enz; BENTO, Emílio José. Retórica e discurso - fronteiras e interfaces: das origens aos desdobramentos atuais - Homenagem à professora Lineide do Lago Salvador Mosca. Campinas: Pontes, 2019, pp. 47-67.

BÍBLIA DE Jerusalém. 10. reimp. Coord. Gilberto da Silva Gorgulho, Ivo Storniolo e Ana Flora Anderson. São Paulo: Paulus, 2015.

BOXER, Charles R. A Igreja militante e a expansão ibérica (1440-1770). Trad. Vera Maria Pereira. São Paulo: Companhia das Letras, 2007.

CONCÍlIO ECUMÊNICO de Trento (1545-1563) - Contra as inovações doutrinárias dos protestantes. Petrópolis: Vozes, 1953.

HANSEN, João Adolfo. Retórica e actio nos discursos coloniais. In: DAHER, Andrea. Oral por escrito: a oralidade na ordem da escrita, da retórica à literatura. Chapecó/ Florianópolis: Argos/Editora UFSC, 2018, pp. 61-85.

\footnotetext{
${ }_{25}$ Sob esse aspecto, o Sermão da primeira sexta-feira da Quaresma, pregado em 1651, conversaria com a Relação da Missão de Ibiapaba, anos à frente, mediante a premissa de que Portugal representaria o Quinto Império. De acordo com Fernanda dos Santos (2018, p. 66): "A ideia naturalizada de que os povos indígenas servem de coadjuvantes e que suas decisões de se confederarem aos holandeses se deve a uma fragilidade espiritual originada na inocência desenvolve-se, segundo toda a argumentação no relato, devido à sua falta da verdadeira fé (o cristianismo católico romano sob a égide de Portugal), o que favorece a ação do mal. A ideia dialoga, claramente, com as teorias quinto-imperialistas”.
} 
HANSEN, João Adolfo. O discreto. In: CUNHA, Cilaine Alves; LAUDANNA, Mayra (Orgs.). Agudezas seiscentistas e outros ensaios. São Paulo: Edusp, 2019a, pp. 97-122.

HANSEN, João Adolfo. Razão de Estado. In: Agudezas seiscentistas e outros ensaios. Org. Cilaine Alves Cunha; Mayra Laudanna. São Paulo: Edusp, 2019b, pp. 75-96.

HÖFFNER, Joseph. Colonização e Evangelho: ética da colonização espanhola no Século de Ouro. 3. ed. Trad. José Wisniewski Filho. Rio de Janeiro: Presença, 1986.

LACHAT, Marcelo. Os sermões de quarta-feira de cinza do Padre Antônio Vieira e a Arte de morrer estoico-cristã. Revista Literatura e Sociedade, n. 23, 2016, pp. 11-26.

LEMOS, Ainda; RAMON, Micaela. Introdução. In: Obra completa, T. II, V. II - Sermão da sexagésima e Sermões da quaresma. São Paulo: Loyola, 2015, pp. 9-27.

LIMA, Luís Filipe Silvério. Padre Vieira: sonhos proféticos, profecias oníricas: o tempo do Quinto Império nos sermões de Xavier Dormindo. São Paulo: Humanitas, 2004.

LUZ, Guilherme do Amaral. Produção da concórdia: poética do poder na América portuguesa. In: Flores do desengano: poética do poder na América portuguesa. São Paulo: Fap-Unifesp, 2013, pp. 33-56.

MAQUIAVEL, Nicolò. O príncipe. Trad. Maurício Santana Dias. São Paulo: Penguin Books/ Companhia das Letras, 2010.

MARTINI, Marcus de. A alegoria nos sermões de Padre Antônio Vieira: algumas questões sobre seu emprego e terminologia. Revista Letras, Especial n. 1, Santa Maria, 2019, pp. 89-120.

MIRANDA, Margarida. Sem a voz que os animou, ainda ressuscitados são cadáveres: actio e declamatio na Formação de Vieira, pregador. Revista Humanitas, n. 6o, 2008, pp. 267-282.

MUHANA, Adma. Introdução. In: Os autos do processo de Vieira na Inquisição (166o-1668). São Paulo: Edusp, 2008, pp. 13-29.

PÉCORA, Alcir. Vieira e a condução do índio ao corpo místico do império português (Maranhão, 1652-1661). In: COSTIGAN, Lúcia Helena (Org.). Diálogos da conversão. Campinas: Editora Unicamp, 2005, pp. 83-98.

PÉCORA, Alcir. Teatro do sacramento: a unidade teológico-retórico-política dos sermões de Antônio Vieira. 2. ed. Campinas/São Paulo: Editora Unicamp/Edusp, 2008.

PÉCORA, Alcir. A arte de morrer, segundo Vieira. In: VIEIRA, Antônio. Sermões de quarta-feira de cinza. Org. Alcir Pécora. Campinas: Editora Unicamp, 2016, pp. 9-66.

PERELMAN, Chaïm; OBRECHTS-TYTECA, Lucie. Tratado da argumentação: a nova Retórica. Trad. Maria Ermantina Galvão G. Pereira. São Paulo: Martins Fontes, 1996. 
SANTOS, Fernanda Cristina da Encarnação dos. A retórica da alteridade na "Relação da Missão da Serra da Ibiapaba, do Padre Antônio Vieira”. Tese (Doutorado em Letras) - Universidade Feredal do Espírito Santo (UFES), Vitória, 2018.

VIEIRA, Antônio. Carta 53 - Ao Rei D. João IV. In: Obra completa, T. I, V. I - Cartas diplomáticas. Dir. José Eduardo Franco; Pedro Calafate. Coord. Carlos Maduro. São Paulo: Loyola, 2014a, pp. 293-294.

VIEIRA, Antônio. Carta 54 - Ao Príncipe D. Teodósio. In: Obra completa, T. I, V. I - Cartas diplomáticas. Dir. José Eduardo Franco; Pedro Calafate. Coord. Carlos Maduro. São Paulo: Loyola, 2014b, pp. 295-297.

VIEIRA, Antônio. Sermão da primeira sexta-feira da Quaresma. In: Obra completa, T. II, V. II - Sermão da sexagésima e sermões da Quaresma. Dir. José Eduardo Franco; Pedro Calafate. Coord. Aida Lemos; Micaela Ramon. São Paulo: Loyola, 2015a, pp. 197-225.

VIEIRA, Antônio. Sermão da sexagésima. In: Obra completa, T. II, V. II - Sermão da sexagésima e sermões da Quaresma. Dir. José Eduardo Franco; Pedro Calafate. Coord. Aida Lemos; Micaela Ramon. São Paulo: Loyola, 2015b, pp. 43-73.

VIEIRA, Antônio. Sermão pelo bom sucesso das armas de Portugal contra as de Holanda. In: Obra completa, T. II, V. XIII - Sermões de incidência política. Dir. José Eduardo Franco; Pedro Calafate. Coord. Luís Machado de Abreu. São Paulo: Loyola, 2015c, pp. 73-95.

Recebido: 29/1/2020

Aceito: $15 / 7 / 2020$

Publicado: 2/12/2020

Remate de Males, Campinas-SP, v.40, n.2, pp. 751-766, jul./dez. 2020 - 766 